\title{
The inheritance of female polymorphism in the damselfly Ischnura graellsii (Rambur) (Odonata: Coenagrionidae)
}

\section{A. Cordero}

Area de Ecoloxía, Facultade de Bioloxía, Universidade de Santiago de Compostela, 15071 Santiago, Galicia, Spain.

The damselfly Ischnura graellsii has three female coloration patterns: the male-like coloured or androchromatypic (A) females, and two gynochromatypic females: infuscans (olive-green to brown females, I), and aurantiaca (orange to brown females, $O$ ). The inheritance of this polymorphism was studied by rearing the offspring of 33 laboratory crosses. Fourteen $F_{1}$, eight $F_{2}$ and eleven $F_{3}$ crosses produced more than 2400 adults in laboratory conditions. Results of these crosses indicate: (1) the progeny of one female can consist of one, two or all phenotypes; (2) when two phenotypes occur the ratio is $1: 1$ or $3: 1$; and (3) when all phenotypes occur the ratio is $2: 1: 1$ for $A: I: O$ females. The simplest hypothesis to explain these results is that three alleles of one autosomal locus control this polymorphism. The androchromatypic allele $\left(\mathrm{p}^{\mathrm{a}}\right)$ is dominant over both gynochromatypic alleles, and infuscans $\left(\mathrm{p}^{\mathrm{i}}\right)$ over aurantiaca $\left(\mathrm{p}^{\circ}\right)$ (Dominance: $p^{a}>p^{i}>p^{0}$ ). Males possess all six possible genotypes but only one phenotype $\left(p^{a}\right)$. All matings were compatible with the hypothesis, and the presence of all genotypes was proved with the matings obtained. Hypotheses about the maintenance of female polymorphism in Ischnura damselfties so far studied are revised.

\section{INTRODUCTION}

Many damselfly species have polymorphic females, one morph resembles the male (which is monomorphic), the other females being more or less dissimilar. In this paper, I will call "androchromatypic" the females with male coloration pattern and "gynochromatypic" the others, using the terminology proposed by Hilton (1987). This kind of polymorphism is common in the family Coenagrionidae. European species of Pyrrhosoma, Ceriagrion, Ischnura, and Enallagma are particularly polymorphic, and most Coenagrion species show many female coloration patterns (d'Aguilar et al., 1985; Askew, 1988), but there is no clear evidence whether they are age-related colour phases or genetically distinct female types. Female polymorphism has also been noted in Polythoridae (Bick and Bick, 1986), Calopterygidae (Dumont, 1972), Libellulidae (D. R. Paulson, personal communication to Robertson, 1985; Kumar, 1988) and Aeshnidae (Corbet, 1986). Female polymorphism is therefore a common phenomenon in the order Odonata.

Johnson $(1964,1966)$ made the first and only genetic studies of this polymorphism. He showed that in Ischnura damula and I. demorsa there are two female phenotypes, and that the inheritance may be explained by means one autosomical locus with sex-restricted expression, androchromatypic females being homozygous recessive $(\mathrm{hh})$, and gynochromatypic females heterozygous $\left(\mathrm{h}^{+} \mathrm{h}\right)$ and homozygous dominant $\left(\mathrm{h}^{+} \mathrm{h}^{+}\right)$.

In I. graellsii there are three female phenotypes, which show different colour changes throughout sexual maturation (fig. 1) (Cordero, 1987). Androchromatypic females (A), are blue in mature phase, as well as the males. There are gynochromatypic females of the aurantiaca form (O), and of the infuscans form (I), both showing brown thorax in mature phase, but different young phases (fig. 1). It is possible to differentiate the female phenotypes in all colour phases by means of the extension of antehumeral stripes of thorax and a black spot on the dorsum of the eighth abdominal segment (Cordero, 1987).

This polymorphism could be explained by an hypothesis similar to that described for I. damula and $I$. demorsa, but with codominance relationships between the two alleles of the locus "p" (polymorphism), A females being homozygous pp, O females homozygous $\mathrm{p}^{+} \mathrm{p}^{+}$and I females heterozygous $\mathrm{p}^{+} \mathrm{p}$ (Cordero, 1987). The same hypothesis was proposed by Hinnekint (1987) for 


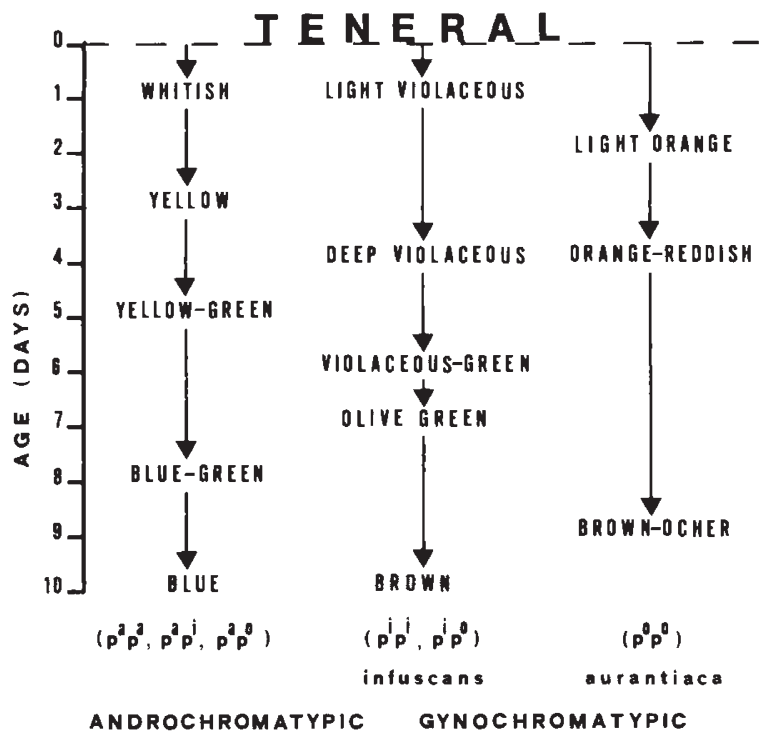

Figure 1 The relationship between thoracic colour changes and age in the different phenotypes of $I$. graellsii. Proposed genotypes are shown in parenthesis. Teneral are newly emerged individuals. Sexual maturation is obtained after $5-6$ days.

I. elegans, which also has three female phenotypes.

In this paper I present the results of controlled laboratory matings in order to test this hypothesis, and review how female polymorphism could be maintained in natural populations of Ischnura damselflies.

\section{METHODS}

The scarcity of genetic studies with dragonflies may be explained by the difficulty of obtaining laboratory matings and the rearing of a great number of larvae in small spaces. This study was made with adults of $I$. graellsii (a small damselfly common in the Iberian Peninsula) obtained from different populations of Pontevedra (NW Spain).

Five insectaries of $50 \times 50 \times 50$ (or 70 ) $\mathrm{cm}$ with numerous wood switchs as perching substrates were used to obtain matings. Insectaries were covered with aluminium foil, which reflects sufficient light and impedes escape responses (Johnson, 1965), and several culture bottles of Drosophila were added to supply food. Insectaries were placed in a chamber maintained at $21-23^{\circ} \mathrm{C}$, 60-80 per cent humidity and a photoperiod of 15L:9D hours. In these conditions matings of $I$. graellsii were easy to obtain. Maximum longevity was 40 days, longer than the one month observed in the field (Cordero, 1987). In the insectaries I was also able to elicit mating of I. elegans, I, pumilio, Ceriagrion tenellum, Lestes viridis, $L$. virens, L. barbarus and L. dryas.

Teneral specimens (1-2 day old adults) were captured in the field and transported to the laboratory for maturing, in order to obtain virgin females to begin the experiments. Each specimen was individually marked with a number on its wings. Mature females were introduced into insectaries of males to mate, and each pair was observed continuously or isolated until copulation was completed. Mated females were placed every 2-3 days in individual oviposition chambers, with damp filter paper as an oviposition substrate. Eggs were maintained in Petri dishes in the same conditions as adults.

After egg eclosion, small larvae were maintained in plastic boxes filled with water, with filter paper as perching substrate, and nauplius of Artemia salina as food (Miguel Conesa, personal communication). Medium-sized larvae $(>6 \mathrm{~mm}$ ) were placed in individual plastic tubes, to avoid cannibalism. This method is timeconsuming because of the need to change the water and add food at least every second day. Large larvae $(>1 \mathrm{~cm})$ were placed in separate cells, but in the same water body, which allowed reducing the frequency of water changes to once each week and standardized breeding conditions. These larvae were fed with Cloeon larvae (Ephemeroptera) and aquatic oligochaeta (Lumbriculus variegatus) until emergence. Last instar larvae were maintained in plastic containers with numerous wood switches as emergence supports.

More than 2400 adults were obtained with this method, from August 1987 to July 1989, with one generation interval of approximately 5 months. All females were assigned to each coloration type in the first hours after emergence, and some were maintained until maturation. All showed the coloration change of their colour type. In the $F_{1}$ all larvae were reared, but in the $F_{2}$, to increase sample size, most male larvae were rejected. in the $F_{3}$, larvae were reared in plastic boxes, without separation during the early instars, because I was only interested in obtaining homozygous lines. For this reason, sample sizes were smaller.

Observed and expected values were compared using $\chi^{2}$ tests.

\section{RESULTS AND DISCUSSION}

\section{Results of laboratory matings}

The segregation of female phenotypes in $F_{1}$ crosses of I. graellsii is shown in table 1. Results obtained 
Table 1 Percentages of the different female phenotypes in the $F_{1}$ generation of Ischnura graellsii. Expected frequencies after the hypothesis of one locus and three alleles are shown in parenthesis (see the text). $N=$ number of females

\begin{tabular}{|c|c|c|c|c|c|c|c|}
\hline \multirow[b]{2}{*}{ Cross code } & \multirow{2}{*}{$\begin{array}{l}\text { Percentage } \\
\text { of males* }\end{array}$} & \multirow[b]{2}{*}{$N$} & \multicolumn{3}{|c|}{ Female phenotype } & \multirow[b]{2}{*}{$\chi^{2}$} & \multirow[b]{2}{*}{$p$} \\
\hline & & & A & 1 & 0 & & \\
\hline \multicolumn{8}{|c|}{ Androchromatypic } \\
\hline$q \mathrm{H}-\delta 1$ & $49 \cdot 1$ & 54 & $48 \cdot 1(50)$ & $51 \cdot 9(50)$ & $0 \cdot 0(0)$ & $0 \cdot 07$ & 0.786 \\
\hline$q \mathbf{R}-\delta 2$ & $50 \cdot 5$ & 47 & $89 \cdot 4(75)$ & $10 \cdot 6(25)$ & $0.0(0)$ & $5 \cdot 17$ & 0.023 \\
\hline$q S-\not 3$ & $44 \cdot 3$ & 59 & $76 \cdot 3(75)$ & $23 \cdot 7(25)$ & $0.0(0)$ & 0.05 & 0.822 \\
\hline $9 \mathrm{~T}-62$ & $48 \cdot 9$ & 44 & $72 \cdot 7(75)$ & $27 \cdot 3(25)$ & $0 \cdot 0(0)$ & $0 \cdot 12$ & 0.728 \\
\hline$\$ B-\delta 4$ & $54 \cdot 8$ & 14 & $100 \cdot 0(100)$ & $0.0(0)$ & $0.0(0)$ & - & - \\
\hline$q N-65$ & $45 \cdot 0$ & 11 & $45 \cdot 5(50)$ & $36 \cdot 4(25)$ & $18 \cdot 2(25)$ & 0.82 & 0.664 \\
\hline \multicolumn{8}{|l|}{ infuscans } \\
\hline$q \mathrm{C}-36$ & $55 \cdot 9$ & 30 & $0.0(0)$ & $100 \cdot 0(100)$ & $0 \cdot 0(0)$ & - & - \\
\hline$q \mathbf{J}-\delta 4$ & $41 \cdot 3$ & 27 & $0 \cdot 0(0)$ & $100 \cdot 0(100)$ & $0 \cdot 0(0)$ & - & - \\
\hline$q \mathrm{~K}-\delta 7$ & $41 \cdot 7$ & 28 & $0 \cdot 0(0)$ & $100 \cdot 0(100)$ & $0 \cdot 0(0)$ & - & - \\
\hline$q \mathrm{~L}-\not 88$ & $41 \cdot 7$ & 32 & $0.0(0)$ & $53 \cdot 1(50)$ & $46 \cdot 9(50)$ & 0.13 & 0.724 \\
\hline \multicolumn{8}{|l|}{ aurantiaca } \\
\hline १M- $\$ 9$ & $50 \cdot 0$ & 44 & $0.0(0)$ & $40.9(50)$ & $59 \cdot 1(50)$ & $1 \cdot 45$ & $0 \cdot 228$ \\
\hline$q P-\not 5$ & $54 \cdot 4$ & 46 & $0.0(0)$ & $43 \cdot 5(50)$ & $56 \cdot 5(50)$ & 0.78 & 0.376 \\
\hline$q U-\delta 3$ & $49 \cdot 0$ & 51 & $49 \cdot 0(50)$ & $0.0(0)$ & $51 \cdot 0(50)$ & 0.02 & 0.889 \\
\hline$q \mathrm{X}-\delta 2$ & $50 \cdot 5$ & 49 & $40 \cdot 8(50)$ & $59 \cdot 2(50)$ & $0.0(0)$ & $1 \cdot 65$ & 0.199 \\
\hline
\end{tabular}

* Obtained from adults.

indicate that: (1) a single female may produce progeny of one, two or three female phenotypes; (2) if two phenotypes are present, the ratio is $1: 1$ or $3: 1$; and (3) when all phenotypes are present the ratio is $2: 1: 1$ for $\mathrm{A}: \mathrm{I}: \mathrm{O}$ females. These results reject the hypothesis of one autosomal locus with two alleles (Cordero, 1987), because if A and O females are homozygous for different alleles, they cannot be present in the same progeny from a single-pair mating.

The simplest hypothesis that explains the observed $F_{1}$ segregation, postulates the existence of one autosomal locus with three alleles, $p^{a}, p^{i}$ and $\mathrm{p}^{\circ}$, with dominance relationships: $\mathrm{p}^{\mathrm{a}}>\mathrm{p}^{\mathrm{i}}>\mathrm{p}^{\circ}$. On this hypothesis, A females may have three possible genotypes: $p^{a} p^{a}, p^{a} p^{i}$ and $p^{a} p^{o}$; I females two genotypes: $p^{i} p^{i}$ and $p^{i} p^{\circ}$; and $O$ females one genotype: $\mathrm{p}^{\circ} \mathrm{p}^{\circ}$. Males could have all genotypes, but only one phenotype. Almost all crosses agreed with this hypothesis. The progeny of female $R$ (table 1) had more A females than expected ( $P=0.023$ ), nevertheless, when both crosses of male 2 with A females are considered jointly, there are no differences from expected $(P=0 \cdot 164)$.

Males crossed with different females (males 2, 3, 4 and 5) showed one genotype consistent with all crosses. The progeny of female $\mathrm{N}$ are very interesting, because all phenotypes are present, indicating a cross with two heterozygotes for different alleles: male 5 is judged to be $\mathrm{p}^{\mathrm{i}} \mathrm{p}^{\circ}$ (as indicated by his cross with female $P$ ) and female
$\mathrm{N}$ to be $\mathrm{p}^{\mathrm{a}} \mathrm{p}^{\circ}$ (because she is an $\mathrm{A}$ female with $\mathrm{O}$ daughters).

To test this hypothesis further, I made $8 \mathrm{~F}_{2}$ crosses, results of which are shown in table 2 . All crosses were consistent with the hypothesis and with the genotypes assigned to $F_{1}$ individuals. This generation yielded a second mating with all female phenotypes in the progeny: the cross between female $\mathrm{N} 1$, whose genotype deduced from the $\mathrm{F}_{1}$ results should be $\mathrm{p}^{\mathrm{i}} \mathrm{p}^{\mathrm{o}}$, and male $\mathrm{X} 1$, with genotype $\mathrm{p}^{\mathrm{a}} \mathrm{p}^{\mathrm{o}}$ (indicated by the segregation in his matings with the three female penotypes).

A third generation was reared in order to obtain some homozygous lines. Results of this $\mathrm{F}_{3}$ are shown in table 3 . All crosses agreed with expected following the genotypes assigned to each individual, excepting the progeny of female $\mathrm{H} 15$, which yielded a ratio $1 \mathrm{~A}: 1$ I while the expected was $3 \mathrm{~A}: 1 \mathrm{I}$. This cross gave only 18 females, and I assume that this segregation reflects sampling error.

An important result of this work is that androchromatypic allele is dominant in $I$. graellsii, while in $I$. damula and $I$. demorsa it is recessive (Johnson, 1964, 1966). The biological significance of this fact is not evident.

Taking into account all matings obtained, the existence of all genotypes proposed by the hypothesis was demonstrated, as the analysis of tables $1-3$ reveals. The sex-ratio (tables $1-3$ ) is $1: 1$ excepting the cross of female U1, with only 40 per 
Table 2 Percentages of the different female phenotypes in the $F_{2}$ generation of $I$. graellsii. Expected frequences are in parenthesis. The letter which identifies each individual is the code of the parental female of the $\mathrm{F}_{1} . N=$ number of females

\begin{tabular}{|c|c|c|c|c|c|c|c|}
\hline \multirow[b]{2}{*}{ Cross code } & \multirow{2}{*}{$\begin{array}{l}\text { Percentage } \\
\text { of males* }\end{array}$} & \multirow[b]{2}{*}{$N$} & \multicolumn{3}{|c|}{ Female phenotype } & \multirow[b]{2}{*}{$\chi^{2}$} & \multirow[b]{2}{*}{$p$} \\
\hline & & & A & I & $\mathrm{O}$ & & \\
\hline \multicolumn{8}{|c|}{ Androchromatypic } \\
\hline ९U1-ð̛M1 & $40 \cdot 0$ & 69 & $50 \cdot 7(50)$ & $0.0(0)$ & $49 \cdot 3(50)$ & $0 \cdot 01$ & 0.904 \\
\hline$q S 1-\partial \times 1$ & $45 \cdot 7$ & 57 & $100 \cdot 0(100)$ & $0.0(0)$ & $0.0(0)$ & - & - \\
\hline$q \mathbf{H} 1-\delta \mathrm{S} 2$ & $56 \cdot 0$ & 67 & $100 \cdot 0(100)$ & $0.0(0)$ & $0.0(0)$ & - & - \\
\hline \multicolumn{8}{|l|}{ infuscans } \\
\hline$q \mathrm{~S} 3-ð \mathrm{C} 1$ & $55 \cdot 1$ & 71 & $0.0(0)$ & $78 \cdot 9(75)$ & $21 \cdot 1(25)$ & 0.57 & 0.451 \\
\hline$\varsubsetneqq \mathrm{C} 2-\delta \mathrm{C} 1$ & $52 \cdot 4$ & 65 & $0.0(0)$ & $100 \cdot 0(100)$ & $0.0(0)$ & - & - \\
\hline$q N 1-\succsim X 1$ & $51 \cdot 5$ & 64 & $54 \cdot 7(50)$ & $26 \cdot 6(25)$ & $18 \cdot 8(25)$ & $1 \cdot 34$ & 0.511 \\
\hline \multicolumn{8}{|l|}{ aurantiaca } \\
\hline$q M 2-\delta^{\wedge} M 3$ & $55 \cdot 9$ & 50 & $0.0(0)$ & $46 \cdot 0(50)$ & $54 \cdot 0(50)$ & 0.32 & 0.572 \\
\hline$q \mathrm{P} 1-\delta \mathrm{X} 1$ & $48 \cdot 4$ & 62 & $46 \cdot 8(50)$ & $0.0(0)$ & $53 \cdot 2(50)$ & $0 \cdot 26$ & 0.612 \\
\hline
\end{tabular}

* Obtained from larvae.

Table 3 Percentages of the different female phenotypes in the $F_{3}$ generation of $I$. graellsii. Expected frequences are in parenthesis. First letter and number which identifies each individual is the code of the parental female of the $\mathrm{F}_{2} . N=$ number of females

\begin{tabular}{|c|c|c|c|c|c|c|c|}
\hline \multirow[b]{2}{*}{ Cross code } & \multirow{2}{*}{$\begin{array}{l}\text { Percentage } \\
\text { of males* }\end{array}$} & \multirow[b]{2}{*}{$N$} & \multicolumn{3}{|c|}{ Female phenotype } & \multirow[b]{2}{*}{$\chi^{2}$} & \multirow[b]{2}{*}{$p$} \\
\hline & & & A & I & $\mathrm{O}$ & & \\
\hline \multicolumn{8}{|c|}{ Androchromatypic } \\
\hline qH11- ${ }^{*} \mathrm{H} 12$ & $40 \cdot 7$ & 32 & $100 \cdot 0(100)$ & $0.0(0)$ & $0.0(0)$ & - & - \\
\hline 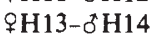 & $41 \cdot 7$ & 21 & $100 \cdot 0(100)$ & $0.0(0)$ & $0.0(0)$ & - & - \\
\hline qH15- ठ’S11 & $62 \cdot 5$ & 18 & $50 \cdot 0(75)$ & $50 \cdot 0(25)$ & $0.0(0)$ & $6 \cdot 00$ & 0.014 \\
\hline qH16- б H17 & $46 \cdot 9$ & 26 & $84 \cdot 6(75)$ & $15 \cdot 4(25)$ & $0.0(0)$ & $1 \cdot 28$ & 0.258 \\
\hline \multicolumn{8}{|l|}{ infuscans } \\
\hline$\$ \mathrm{C} 21-{ }^{\top} \mathrm{C} 22$ & $46 \cdot 9$ & 51 & $0.0(0)$ & $100 \cdot 0(100)$ & $0 \cdot 0(0)$ & - & - \\
\hline \multicolumn{8}{|l|}{ aurantiaca } \\
\hline @U11- б'M21 & $31 \cdot 6$ & 26 & $0 \cdot 0(0)$ & $46 \cdot 2(50)$ & $53 \cdot 8(50)$ & $0 \cdot 15$ & 0.695 \\
\hline १P11-ठ̛ M22 & $49 \cdot 2$ & 30 & $0.0(0)$ & $40 \cdot 0(50)$ & $60 \cdot 0(50)$ & $1 \cdot 20$ & 0.273 \\
\hline १P12- ठ̊P13 & $38 \cdot 5$ & 40 & $47 \cdot 5(50)$ & $0.0(0)$ & $52 \cdot 5(50)$ & $0 \cdot 10$ & 0.752 \\
\hline १S31- ఫैP14 & $62 \cdot 1$ & 22 & $50 \cdot 0(50)$ & $0.0(0)$ & $50 \cdot 0(50)$ & - & - \\
\hline १P15-ठ̛̃ 12 & $64 \cdot 3$ & 15 & $0.0(0)$ & $0.0(0)$ & $100 \cdot 0(100)$ & - & - \\
\hline qU13- ठैP16 & $41 \cdot 7$ & 28 & $0.0(0)$ & $0.0(0)$ & $100 \cdot 0(100)$ & - & - \\
\hline
\end{tabular}

* Obtained from adults.

cent males $(P=0.020)$, and the cross of female U11, with 32 per cent males $(P=0 \cdot 023)$. Therefore female biased sex-ratios found by Johnson (1964, 1966) were not observed.

\section{Maintenance of polymorphism}

Androchromatypic females of $I$. graellsii mimic male coloration and behaviour, and males are not able to distinguish these females from other males (Cordero, 1989), as occurs in I. ramburi too (Robertson, 1985). In the insectaries, androchromatypic females refuse a second mating in the same day, which is common in gynochromatypic females (Cordero, 1989). As suggested by Robertson (1985), this difference may have an adaptive significance if it is taken into account that copulations in this species may exceed 5 hours (time during which females are unable to eat and are perhaps more exposed to predation) and that oncemated females are able to fertilize all eggs laid throughout their lifespan (Cordero, in press). Androchromatypic females may be favoured by high density conditions, when the encounters with males are very common. For Hinnekint (1987) this fact and the existence of pluriannual cycles with 
Table 4 Percentages of the different female phenotypes in five natural populations of $I$. graellsii of Galicia (NW Spain). All samples in the same generation interval are considered jointly

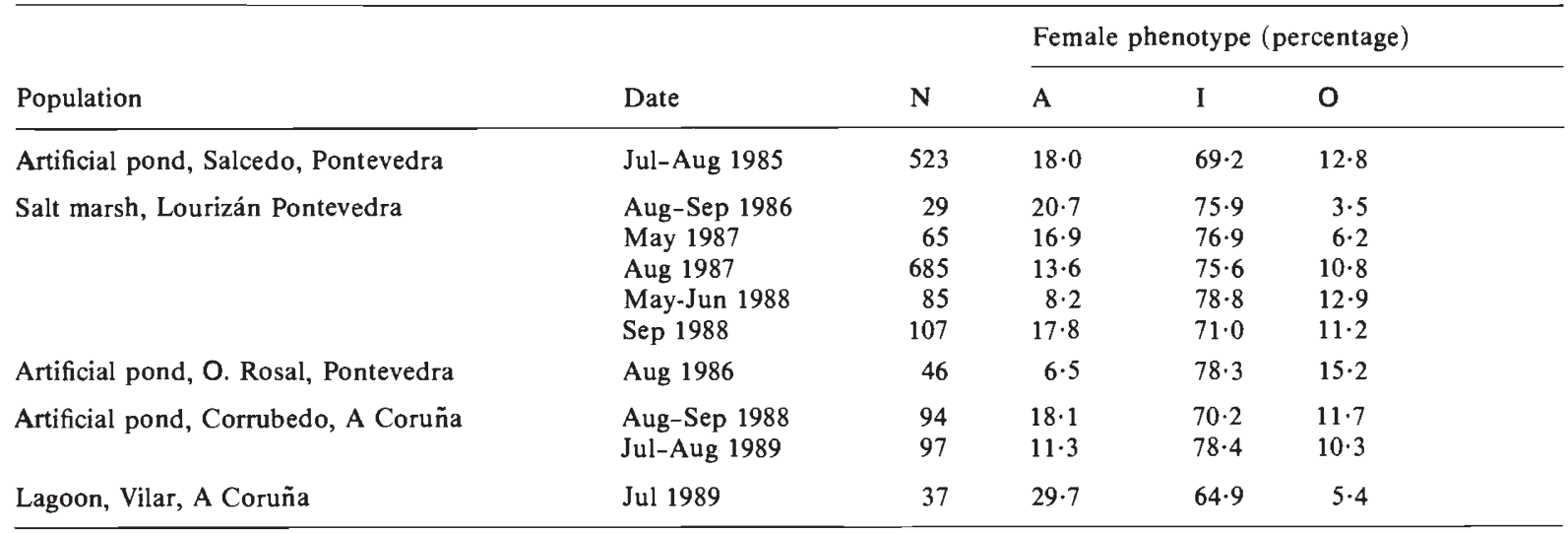

variation in population density, explain the maintenance of female polymorphism in I. elegans.

In an alternative explanation proposed by Johnson (1975) for I. damula and I. demorsa, androchromatypic females may offer increased reproductive isolation between the species in sympatry, but are perhaps more vulnerable to visual predators, as a result of their conspicuous coloration. Gynochromatypic females engage in heterospecific matings when the species are sympatric, thereby lowering their reproductive potentials (Johnson, 1975).

The relative advantage of androchromatypic females probably differs for each species and in different ecological conditions for the same species. Robertson (personal communication) in a comparative study of the thirteen North American species of Ischnura found extremes in androchromatypic frequencies, resemblance to males, copulation duration and frequency, and postcopulatory guarding. This comparative study generally supports the hypothesis that androchromatypic frequencies are related to the mating behaviour of each species. Thompson (1989) was unable to find any difference between andro- and gynochromatypic females of Coenagrion puella in date of maturation, size, mature lifespan, and number of clutches of eggs laid. Furthermore there is no supporting evidence for higher predation risks for andro- than gynochromatypic females of any species.

Gynochromatypic infuscans females are the majority of $I$. graellsii females: 65-79 per cent in five sampled populations, androchromatypic (7-30 per cent) and aurantiaca (4-15 per cent) are less common (table 4). Preliminary data suggest that androchromatypic females are more frequent in dense populations, but this is difficult to test because $I$. graellsii is very rarely seen forming low density populations (the only low density population sampled was at an artificial pond at O Rosal, Pontevedra, table 4). Furthermore, as table 4 shows, the frequency of androchromatypic females varies between 8 and 21 per cent in the same population at different dates. If males have genetically determined preference to mate with one type of female, as reported in I. damula and I. demorsa (Johnson, 1975), then natural selection can be more intense, but this preference does not exist in I. ramburi (Robertson, 1985) or in I. graellsii (Cordero, unpublished data). Finally, the existence of fitness differences between andro- and gynochromatypic larvae is unknown, although the larva is the longest phase of most odonates.

To explain the maintenance of female polymorphism of $I$. graellsii the study of the reproductive strategies of different types of females in different ecological conditions is needed.

Acknowledgements I wish to thank Hugh H. Robertson, Gonzalo Alvarez and Emilio Valadé for their comments for the manuscript. Enrique Martínez-Ansemil identified the Lumbriculus. This paper was presented to the "X International Symposium of Odonatology", Johnson City, Tennessee, USA, in August 1989. This study was aided by a fellowship from the Spanish Ministry of Education and Science to the author (Plan de Formación del Profesorado y del Personal Investigador).

\section{REFERENCES}

AGUILAR, J. D', DOMMANGET, J.-L. AND PRECHAC, R. 1985. Guide des Libellules d'Europe et d'Afrique du Nord. Delachaux \& Niestlé, Neuchatel-Paris. 
ASKEW, R. R. 1988. The dragonflies of Europe. Harley Books, Martins.

BICK, G. H. AND BICK, J. C. 1986. The genus Polythore exclusive of the picta group (Zygoptera: Polythoridae). Ondonatologica, 15(3), 245-273.

CORBET, P. S. 1986. In Corbet, P. S. (ed.) Current Topics in Dragonfly Biology, p. 16. Soc. int. odonatol. rapid Comm. (Suppl.), $\mathrm{x}+33 \mathrm{pp}$.

CORDERO, A. 1987. Estructura de población en Ischnura graellsi Rambur, 1842 (Zygop, Coenagrionidae). Bol. Asoc. esp. Entom., 11, 269-286.

CORDERO, A. 1989. Reproductive behaviour of Ischnura graellsii (Rambur) (Zygoptera: Coenagrionidae). Odonatologica, 18(3), 237-244.

CORDERO, A. The adaptative significance of the prolonged copulations of the damselfly, Ischnura graellsii (Odonata: Coenagrionidae). Anim. Behav. (In press).

DUMONT, H. J. 1972. The taxonomic status of Calopteryx xanthostoma (Charpentier, 1825) (Zygoptera: Calopterygidae). Odonatologica, 1(1), 21-29.

HILTON, D. F. J. 1987. A terminology for females with colour patterns that mimic males. Ent. News, 98(5), 221-223.
HINNEKINT, B. O. N. 1987. Population dynamics of Ischnura e. elegans (Vander Linden) (Insecta: Odonata) with special reference to morphological colour changes, female polymorphism, multiannual cycles and their influence on behaviour. Hydrobiologic, 146, 3-31.

JOHNSON, C. 1964. The inheritance of female dimorphism in the damselfly, Ischnura damula. Genetics, 49, 513-519.

JOHNSON, C. 1965. Mating and oviposition of damselflies in the laboratory. Can Ent., 97, 321-326.

JOHNSON, C. 1966. Genetics of female dimorphism in Ischnura demorsa. Heredity, 21, 453-459.

JOHNSON, C. 1975. Polymorphism and natural selection in Ischnuran damselflies. Evol. Theory, 1, 81-90.

KUMAR, A. 1988. On the andromorphic female of Neurothemis t. tullia (Dru.) (Anisoptera: Libellulidae), Notul. Odonatol, $3(1), 14-15$.

ROBERTSON, H. M. 1985. Female dimorphism and mating behaviour in a damselfly, Ischnura ramburi: females mimicking males. Anim. Behav., 33, 805-809.

THOMPSON, D. J. 1989. Lifetime reproductive success in andromorph females of the damselfly Coenagrion puella (L.) (Zygoptera: Coenagrionidae). Odonatologica, 18(2), 209-213. 